\title{
Breeding New Knowledge at Home: The Case of the Albanian Olive Friendship Tree in China
}

\section{Sigrid Schmalzer 舒喜乐 ${ }^{1}$}

(History Department, University of Massachusetts Amherst, Amherst, MA 01003, US)

\begin{abstract}
This article uses the case of the Sino-Albanian Friendship Trees to examine the significance and the limits of transnational scientific exchange in China during the 1960s and 1970s. In 1964, Albania gave ten thousand olive trees to China as a symbol of the eternal friendship of the Chinese and Albanian people; it was then up to Chinese agricultural scientists and farmers to find suitable means to propagate and cultivate them. The author finds that, though the olive trees served as symbols of international friendship and scientific exchange, knowledge about olive trees produced and circulated in the PRC reflected science in context (that is, science within the national-level political context of 1960s-1970s China) more than knowledge in transit (that is, the transnational circulation of knowledge). The importation of olive trees from Albania ended up offering a new application for Chinese agricultural knowledge and for quintessentially "Cultural Revolution"-era systems of knowledge production and circulation.
\end{abstract}

Keywords: transnational scientific exchange, Sino-Albanian Friendship Trees, agricultural science, science in 1960s-1970s China

摘 要: 本文以 “中阿友谊树” 为例, 考察了 20 世纪六七十年代在中国发生的跨国科学 交流的意义与局限。1964 年，阿尔巴尼亚向中国赠送了一万棵橄榄树，作为中阿两国人 民永恒友谊的象征。这些橄榄树交由中国的农业科学家和农民来寻找合适的方式进行繁 殖和栽培。作者发现, 虽然橄榄树被用作国际友谊和科学交流的象征, 但与其说产生和 流传于中国的、与橄榄树相关的知识是 “被传输的知识” (即跨国流动的知识), 冊宁说 它们是 “背景中的科学” (即 20 世纪六七十年代中国国内政治背景下的科学)。从阿尔巴 尼亚入境的橄榄树, 最终成为中国本土农业知识和 “文化大革命” 时期知识生产和流通 系统的又一个应用实例。

关键词: 跨国科学交流, 中阿友谊树, 农业科学, 20 世纪六七十年代中国的科学

1 Research interests: Social, cultural, and political aspects of the history of science in modern China; the history of science activism transnationally. Email: sigrid@history.umass.edu 


\section{Introduction}

This is the story of the Albanian olive trees in China, as it was told until 1978, when 1 China began its period of economic reforms and the two countries finally finished parting ways:

In 1964, the Chinese Premier Zhou Enlai 周恩来 (1898-1976) visited Albania on an official delegation that formalized the Sino-Albanian alliance. In joining forces, China and Albania were standing strong against the Soviet Union, with which each state had political conflicts and whose "revisionism" both opposed on ideological grounds. As a token of Sino-Albanian friendship, Mehmet Shehu (second only to Enver Hoxha among the Albanian leaders) bestowed upon Zhou ten thousand olive trees. The trees sailed over the seas to the port of Zhanjiang in southern Guangdong, whence they were distributed across eight Chinese provinces. Zhou Enlai planted the first tree with his own hands at the Haikou Tree Farm in Yunnan, and when Shehu visited China in 1966 he personally took up a hoe to tend one of the growing orchards ("Xiangzheng Zhongguo A'erbaniya" 1970). A delegation of Albanian olive tree experts toured the farms in the summer of 1972, working tirelessly under often brutal conditions to demonstrate the commitments of “brothers" (兄弟) and “comrades at arms" (战友) ("Youyi zhi shu" 1972). By 1975, the Albanian olive trees and their descendants had been planted in five hundred Chinese localities spanning thirteen provinces (Bureau of Forestry, Ministry of Agriculture and Forestry 1975, preface 1). Having plied the seas and having withstood nature's myriad challenges, the trees had bloomed and born fruit, and so had "cemented the revolutionary militant friendship between China and Albania” (凝结中阿两国人民革命战斗情谊) and manifested the old adage, sanctified by Mao, “A bosom friend afar brings a distant land near" (海内存知已, 天涯若比邻) (“Xiangzheng Zhongguo A'erbaniya" 1970).

\section{On historical significance}

When I tell Westerners outside academia that I study the history of science in China, I often find myself having to defend this subject as not "esoteric," but rather of central importance in understanding our modern world and our collective future. But I admit it has been harder to say with a straight face that I am researching the history of Albanian olive trees in socialist China. This topic seems beyond esoteric and almost self-indulgent. I find myself thinking of the critiques of bourgeois popular science in the nineteenth and early twentieth centuries in England, Germany, and China, where elites were said to offer the masses nothing but "little dainties" (Schmalzer 2008, 31)-precious little topics like giraffes and baobab trees that served to "divert" attention from areas of science that would actually benefit the working classes or even 
help liberate them (Hopwood 1996, 131). As one critic in England put it, "We are anxiously looking for a new system of social organization . . . and Lord Brougham thinks to stop our mouths with kangaroos" (Shapin and Barnes 1976, 240).

Of course it is possible to use apparently esoteric topics to shed light on big and important questions: consider Robert Darnton's use of a cat massacre to explore resistance among apprentice printers in the early stages of capitalism, or Clifford Geertz's detailed analysis of cockfighting as a window into power and social relationships in Bali. But in the case of the Sino-Albanian olive trees, this was not my motivation, and in fact I had very little choice in the matter. I had been asked to write about the circulation of agricultural knowledge between China and Eastern Europe, and so I searched the full array of Mao-era agricultural journals in the Chinese Academic Journals Database for any discussion of Eastern European countries and came up with surprising little. Though they certainly existed, transnational knowledge exchange and technology transfer were very scantily covered in Mao-era agricultural science journals. Only one topic appeared to have generated enough discussion to feed a research paper: the "Sino-Albanian friendship trees" (中阿友谊树). And so, beyond offering a "little dainty," the real purpose of this article is to use the case of the Sino-Albanian friendship trees to explore the significance of, and limits to, transnational knowledge exchange in 1960s-1970s China.

The introduction of olive trees from Albania to China was by no means the only such exchange of plants and animals between China and friendly nations during the Mao era. Besides the famous diplomatic gifts of pandas from China to favored friends (Songster 2018), scattered reports document the “friendship grass" (友谊草, comfrey) that came from North Korea and was said to be useful as medicine and for forage; Pakistan's quiet transfer to China of the International Rice Research Institute's high-yielding variety of rice, IR-8, before China had reestablished ties with US-supported institutions; and the African-originating tilapia provided to China by Vietnam; among other travelers. From Albania, China also received a new wheat variety, and to Albania China sent twenty thousand fingerlings of carp to help them establish freshwater aquaculture ("Woguo li lian yumiao" 1959, 22). All of these exchanges helped highlight the socialist principle of international solidarity, but none (barring, of course, the pandas, which were of a different sort altogether) received the attention that the Sino-Albanian friendship trees garnered, not only in People's Daily but in agricultural science journals as well.

To what extent did such transfers involve substantial exchanges of knowledge? Based on the evidence regarding the Sino-Albanian friendship trees, it appears that the most substantial and long-lasting "knowledge" transplanted was encoded in the genetic resources by the scientists and farmers who bred the organisms. Ten thousand Albanian olive trees arrived in China, but it was largely up to Chinese farmers, 
technicians, and scientists to figure out how to make them reproduce and bear fruit. Albanian experts visited China, and Chinese scientists, farmers, and cadres no doubt benefited from attending their presentations and reading their published lectures on olive cultivation. However, the sources offer little testimony on the significance of Albanian knowledge; rather, they suggest a greater role for local agricultural knowledge and for quintessentially "Cultural Revolution"-era systems of knowledge production and exchange. In other words, despite the effort to use knowledge exchange as a symbol of international friendship, what comes through here is "science in context" rather than the newer STS focus, "knowledge in transit."

Looked at from one direction, this is somewhat surprising. It was, after all, the era of the famous TAZARA "Freedom Railway" project, in which China assisted in the construction of a massive railroad to connect landlocked Zambia to shipping routes through Tanzania, thus bypassing white-ruled Rhodesia and South Africa (Monson 2009). It was also the era of Chinese medical missions in northern Africa, agricultural projects in western Africa, and other efforts to share not only modernizing technologies but also the Maoist philosophy of self-reliance with Third World nations (Zou 2019; Bräutigam 1998; Schmalzer 2014). These specific instances of Chinese participation in global socialist circuits of expertise, ${ }^{2}$ together with broader historical explorations such as those by the Afro-Asian Networks Research Collective (2018), encourage us to take very seriously the "highly mobile activists, writers, scientists, and artists of the Afro-Asian moment" who crossed borders to exchange knowledge (Afro-Asian Networks Research Collective 2018, 178). As Dongxin Zou convincingly argues, based on the history of 1960s and 1970s Chinese medical missions to Algeria, "Mao's China was more internationalistic than xenophobic, tangibly connected with the world by flows of people, ideas, materials, and technologies" (Zou 2019, 5).

And yet, at least in the case of the Albanian olive trees in China, the available evidence lends weight to the concerns of a number of scholars, including historians of science in China, about the concept of "knowledge in transit" and its disproportionate emphasis on "circulation." Fa-ti Fan warns, "The image of circulation tends to impose too much unity, uniformity, and directionality on what was complex, multi-directional, and messy," and moreover sidesteps critical investigations of power relations (Fan 2012, 252). Taking a different tack, Grace Shen has encouraged us to notice the "quiet spaces" that early Chinese geologists created to develop their skills: these "voids and eddies" were just as important as the "flows" of transnational circulation in the emergence of professional geology in Republican-era China (Shen 2013, 260). Global socialist knowledge exchange in the 1960s-1970s was certainly structured by unequal power

2 This was the topic of a workshop held at Columbia University in 2016, titled "Global Circuits of Expertise and the Making of the Post-1945 World: Eastern European and Asian Perspectives," for which this paper was originally written. 
relations, and the political context in China produced its own forces that counteracted the forces of transnational circulation. In this regard, the principle of self-reliance played a particularly important, if somewhat paradoxical, role. Self-reliance was presented as the keystone of 1960s-1970s Chinese scientific development, not only to Chinese audiences at home but also to members of Third World communities, from villagers in Tanzania to Black Panthers in the United States. While the principle of self-reliance undoubtedly succeeded in connecting Maoism to social and political movements around the world, it also helped create "eddies" that kept knowledge more local. As we will see, interest in Albania and its agricultural knowledge proved difficult to sustain in China when self-reliance carried so much political weight, home-grown techniques were ready at hand, and the Chinese natural and political landscapes compelled such serious attention.

\section{The introduction of Albanian olive trees to China}

Until the dissolution of Sino-Albanian friendship in 1978, published accounts of the introduction of olive trees to China centered nearly exclusively on Albania's 1964 gift, and the sheer number of trees transferred in that episode provides some justification for the emphasis. However, there had been earlier introductions. In 1940, a few saplings reportedly were brought to Chongqing, Taiwan, and Fujian. Beginning in 1956, Albania and the Soviet Union sent saplings and seeds. Following the major shipment in 1964, Albania provided additional olive seeds and saplings in 1968, in 1969, and from 1974 to 1976 (Xu 2004, 5). Some accounts published after the Sino-Albanian split bury the 1964 moment within that history ( Xu 1981; Yang 2005), and some call into question the quality of the Albanian trees, recommending that China import trees from Spain or

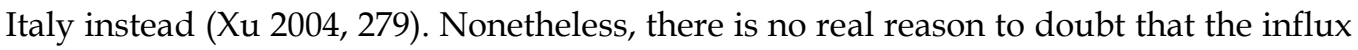
of trees and investment of political energy that came with them in 1964 was a major turning point for olive cultivation in China.

The lead scientist in charge of the olive tree project was $\mathrm{Xu}$ Weiying 徐纬英 (1916-2009), a specialist in forestry who is today popularly recognized for having bred several important varieties of poplar (a tree with strong cultural significance and one of the most important tree species for Chinese industry and for urban beautification efforts), and secondarily for her contributions to introducing olive trees to China (Baidu Baike 2016). $\mathrm{Xu}$ had also been active early in the Chinese Communist Party and participated in agricultural reconstruction at the Institute of Natural Sciences in the revolutionary base area of Yan'an during the 1940s. Her husband was Le Tianyu 乐天 宇 (1901-1984) - an old friend of Mao Zedong's from his Changsha days, the head of the biology department of Yan'an's Institute of Natural Sciences, China's most prominent early Michurinist (that is, Lysenkoist), and perhaps the most influential 
early architect of what would become "mass science" in the Mao era (Reardon-Anderson 1991, 352-359). After 1949, Le Tianyu became the president of China Agricultural University, but he lost his position and most of his political influence when Mao decided he had gone too far in bullying scientists unwilling to adopt the Michurinist line. Le remained active in research, however, and together with $\mathrm{Xu}$ Weiying wrote a comprehensive flora of the Shaan-Gan-Ning area (where Yan'an is situated), published in 1957 (Le and Xu 1957). Xu Weiying was also a strong proponent of Michurinism but, like many other women scientists, did not have the leadership position of her husband. Nor was she apparently implicated in his abuses of power, and she went on to have a robust career in forestry, in 1954 establishing China's first forestry breeding research laboratory at the Central Forestry Scientific Research Institute ("Daonian zhuming linmu yuzhong xuejia" 2009).

In 1963, Xu was dispatched to Albania to study olive cultivation, and she met the boat in Zhanjiang Harbor when the gift of ten thousand trees arrived in 1964 (“A'erbaniya zengsong woguo" 1964). In 1965, Xu co-authored an extensive article discussing olive cultivation in Albania. (The other author was Han Yifan, another woman forestry scientist who had studied in the Soviet Union and was assigned to assist $\mathrm{Xu}$ with the olive work.) ${ }^{3}$ The article noted that olives grew well all over Albania, but especially near the coast and in the hills below 600 meters (the flat lands also were suitable for olive cultivation but tended to be used for other crops). Xu and Han offered a detailed analysis of environmental conditions across Albania (with special attention given to Schkoeder Province, the mountain city of Kruje, and the capital of Tirana), explained the consequences for olive production, and listed which olive varieties did best in which regions ( $\mathrm{Xu}$ and Han 1965). And they ranked the regions of Albania into four categories with respect to olive production: best, good, lacking, and very lacking.

$\mathrm{Xu}$ and Han further sought to identify regions within China that most closely matched Albanian conditions and so presumably would be the most promising candidates for introducing olives in China. First was the Diandong Plateau, exemplified by Kunming and Xichang, which they deemed similar to Sarand Province in Albania (ranked among the most productive olive-producing areas in Albania). The second area was large and had to be subdivided to account for significant differentiation, but included areas in Jiangxi, Hunan, Sichuan, Guangxi, and Guizhou. The third spanned the lower Yangtze and Huai Rivers along with the Bashan Qinling area of southern Shaanxi Province; Nanjing, Wuhan, and Hanzhong were identified as good example

$3 \mathrm{Tu}$ Youyou's recent triumph in winning China's first Nobel Prize in Physiology or Medicine has helped draw attention to the under-studied subject of women scientists in Mao-era China. For an earlier example of such interest, see historian of science Zhang Li's 2013 interview with China Science Daily (Wang 2013). 
sites, but which would need varieties tolerating colder temperatures. The fourth comprised regions in Guangxi and Guangdong (like Nanning and Guangzhou) that had the opposite problem of excessive heat. And the fifth included areas in Shanxi Province. Regarding the different conditions, the authors concluded: "Because of the differences in climatic and soil conditions between China's experimental introduction sites and the original production land of olives in Albania, in the work of introduction and acclimatization, we must provide the most appropriate cultivation technologies in accordance with the natural environmental conditions and characteristics of each of China's introduction sites and with the conditions necessary for olive growth and reproduction in order that the work should achieve success" (Xu and Han 1965, 99). ${ }^{4}$ In this article, $\mathrm{Xu}$ and Han offered a systematic effort to bridge the agricultural environments and scientific literatures of Albania and China that future publications rarely even attempted and probably never matched.

\section{Albanian expertise in China}

The available sources are exceedingly murky on the means by which Chinese scientists, technicians, and farmers learned olive cultivation from their Albanian benefactors. The article by $\mathrm{Xu}$ Weiying and Han Yifan clearly drew in large part from Xu's stay in Albania and moreover was based almost entirely on sources in Albanian, with just one Chinese source on climate science, one FAO source in English on olive cultivation, and one source in Russian. Another delegation of four Chinese agricultural experts spent a year in Albania beginning in October 1964; its members studied olive tree cultivation and olive processing technologies and presumably shared this knowledge with colleagues at home, but I have not found documentation demonstrating the impact of what they learned on Chinese practices (Deng 2014). A 1970 article in People's Daily spoke of Chinese workers and technicians cultivating the trees at each site "under the direction of Albanian experts" (在阿尔巴尼亚专家的指导下), but the article did not elaborate, and it is difficult to imagine that Albanians were in fact staffing all of those far-flung locations or what kind of translation apparatus would have been required for such an endeavor ("Xiangzheng Zhongguo A'erbaniya" 1970). Similar apparently pro-forma references to the guidance of Albanian experts appear periodically in other newspaper and journal articles, without attention to what knowledge was in fact shared (Wuhan Research Institute of Gardening 1975).

A 1972 People's Daily article offers some interesting details in its description of an

4 “由于在我国各引种试验地区的气候、土壤条件与油橄榄原产地阿尔巴尼亚不完全相同, 因此, 在引种驯化工作中, 必须根据我国各引种地点的自然环境条件的特点, 及油橄榄生长发育所需要的 条件, 给予最适宜的栽培技术措施, 使引种工作获得成功。” Here the word “acclimatization” suggests a Michurinist influence, though not necessarily a problematic one given the context. 
exhibit at the Hubei Provincial Forestry Science Research Institute. The space was affectionately called the "Friendship Room" (友谊室): in the entryway, the six Chinese characters “中阿友谊万岁” (Long live the Sino-Albanian friendship) were spelled in olive pits, meticulously selected for equal size; and on the wall were photographs of Albanian "comrades in arms" (战友) who had visited during the past few years to observe the trees cultivated there. That year in August, with temperatures soaring to $39^{\circ} \mathrm{C}$, a team of Albanian experts "came all the way here to promote Sino-Albanian friendship" (为增进中阿友谊, 远道而来). They demonstrated and lectured on the subjects of pruning, grafting, seeding, and pest control. "Under the hot sun, they worked for three or four hours straight, their sweat soaking through their clothes. Chinese comrades kept asking them to rest but they said they were brothers and if there was work to do they should do it together. Looking back on that time spent happily together with their Albanian comrades in arms, the Forestry Science Research Institute comrades said: The friendship fruit from the friendship trees was irrigated by the sweat of Chinese and Albanian people together" ("Youyi zhi shu" 1972). ${ }^{5}$

Many international specialists who have visited China over the past half-century, along with their Chinese hosts, will recognize something of this scene-the presentations, observations, photo opportunities - and may rightly wonder how much actual learning occurred. How important was that visit for the circulation of knowledge, and how much of the sweat served more symbolic (albeit certainly important) political and diplomatic purposes? Returning to the awkward question of significance, while fellow historians are likely to excuse the whimsical topic of the Albanian olive tree in socialist China, it is possible that the olive tree played a "diversionary" role even in its own historical period. The leader of Albania, Enver Hoxha, wrote harshly in an April 20, 1973 diary entry about Chinese "revisionism" (this was, after all, the period when China began renewing relations with the United States) and complained that "the Chinese are publishing nothing about us, apart from welcoming and farewelling of football and volleyball players and Chinese acrobats" (Halliday 1986, 299). 6 Celebrating Sino-Albanian friendship by irrigating olive trees with the pooled sweat of Chinese and Albanian people might arguably fall under a similar category of symbolic friendship without true political commitment.

However, the Albanian experts did more than tour sites and offer lectures under impressively hot suns. They provided education at training centers in three

5 “他们在烈日下, 连续工作三、四个小时, 汗水浸透了衣服。中国同志一再请他们休息, 他们热 情地回答说: “我们是真诚的兄弟, 有事应该共同来做。” 回顾同阿尔巴尼亚战友欢聚的日子, 林业 科学研究所的同志们激动地说: 友谊树结出友谊果, 是中阿两国人民共同用汗水浇灌培育出来的。” 6 There is considerable reason to doubt the genuineness of Hoxha's memoirs, which appear to have been constructed by Hoxha after the fact to suggest an earlier departure from Mao along with other people and ideologies that later fell out of favor. See Mëhilli 2017. 
locations-Kunming, Liuzhou, and Guilin-where "more than one hundred technicians, workers, and cadres came from olive cultivation sites in thirteen provinces and districts to hear the experts systematically explain olive tree distribution, uses, characteristics, raising seedlings, management, the harvesting and processing of the fruit, and disease and pest control" (Youganlan 1973, publisher's note, no page number). ${ }^{7}$ Moreover, their lecture materials were collected and published in 1973 in a volume of 154 pages (Youganlan 1973). The copyright page testifies to an initial print run of fourteen thousand - a number that again highlights the political significance of the exchange. This was far more copies than would have been needed at the five hundred sites, and more than one for each of the original trees. The book - and we can probably assume the same was true of the lectures themselves-was in no way addressed to any specific needs of China. It was framed very much in the manner of, "This is how it is in Albania," leaving it to the Chinese readers to determine how to adapt and use that knowledge.

On their side, the Chinese authors of journal articles on olive tree cultivation seemed to draw little, at least not explicitly, from the Albanian expertise available. A 1973 article from Jiangxi titled "Preliminary Report on Experiments in the Introduction of Olives" appeared to employ Xu Weiying and Han Yifan's article in its attention to climatic comparison between Jiangxi and Albania (Research Institute of Forestry Science in Ganzhou, Jiangxi 1973, 8-11). The major difference was the considerably greater number of rainy days, especially in spring and summer, in Jiangxi compared with Albania. The authors wondered whether this affected the fruiting rate and further pondered whether the effect had been conquered by "acclimatization, changes in the grafting stock, and selection of varieties” (气候的驯化, 砧木的改变, 品种的选择). (The reference to acclimatization again suggests a Michurinist analysis, but these questions are not entirely black and white, for further down the authors expand on the need for "selection of varieties" in asserting their plan to collect different varieties and sort through them to find those best suited to the district.)

Several articles published after the Albanian lectures became available made reference to the guidance provided on propagation. This, of course, was the major challenge facing those charged with physically manifesting the blooming and fruition of Sino-Albanian friendship. The 1972 People's Daily article on the Hubei Research Institute announced that of the 10,000 saplings delivered in 1964, 400 had come to their institute and by 1972 "these olive trees that symbolize the Sino-Albanian friendship have grown from 400 to 1159. Last year 171 of them bloomed and 140 bore fruit, with a harvest of 334 kilos of fresh fruit. This year, 260 trees bloomed, 181 bore fruit, and the

7 “参加学习的有十三个省 (区) 油橄榄种植点的技术人员、工人、干部等一百多人, 专家系统地 讲授了油橄榄的分布、用途、特性、育苗、经营管理、果实的采收与加工，以及病害和虫害的防治。” 
production will be greater than last year" ("Youyi zhi shu" 1972). ${ }^{8}$

An article from Shaanxi published in February 1973 explicitly listed the seven means of propagation described by the Albanian experts (Nanwutai Experiment Station of Shaanxi Forestry Research Institute 1973). They were in fact identical to the seven listed in the book by the Albanian experts, but given that the book itself was not available until July of that year, it appears that the knowledge was obtained from one of the training centers or a visit by the team to Shaanxi. Sadly, however, the authors deemed none of the seven methods workable for their situation. Direct seeding depended on the existence of mature female trees to produce seeds (a chicken-and-egg problem if there ever was one), and moreover with some varieties the germination rate was low and the growth rate slow. Both proposed methods of cuttage had very low survival rates. Germinating from buds required materials unavailable to them. Grafting would require two years to raise the stock trees, and left the grafted trees susceptible to damage from freezing. Making a wound in the tree to promote budding was damaging enough to the original tree that it was rarely done even in Albania. And burying the twigs was so difficult that it was hardly ever used.

Discarding all of these options, the authors resorted to an old Chinese method for hard-to-propagate trees known as air-layering (高空压条, more often called 空中压条, and sometimes in English called marcotting). This is in fact not entirely unlike the practice of making a wound mentioned by the Albanian experts; however, it is done not near the base of the tree but rather on a small branch. The article described how they cut a wound into the branch, filled a piece of plastic with a 3:1 ratio of ox or horse manure and fine river sand, and bound the plastic to the wound with thin rope, leaving it for seven to ten days in partial shade and spraying with water morning and evening until roots began to form. They emphasized that olive trees love sunlight, so too much shade was not advisable. How seriously they had pondered the options suggested by the Albanians before rejecting them we probably cannot know, but a short article published in 1971 documents that before the arrival of the Albanian experts they had already determined to attempt air-layering as a propagation method ("A'erbaniya youganlan zai Hanzhong" 1971).

Another article published around the same time, this one from Lushan in Jiangxi, did not mention the Albanian experts at all but discussed the results of the Lushan Botanical Garden's experiments with a method of propagation on the list advised by the Albanians: cuttage (that is, taking a cutting and encouraging it to root). The researchers had determined that it worked better in fall than in spring, and better in a bed of fine sand than in coarse sand (Lushan Agricultural Bureau and Lushan

8 “这批象征中阿友谊的油橄榄树已经由四百株发展到一千一百五十九株。去年有一百七十一株开 花, 一百四十株结果, 收鲜果三百三十四公斤。今年又有二百六十株开花, 一百八十一株结果, 产 量将比去年有较大的增长。” 
Botanical Garden 1973). Of course, cuttage was a widely known practice and it was not necessary for the researchers to have learned of it from the Albanian experts, but it is nonetheless quite possible that they had heard the relevant lecture and chose to pursue that option.

A 1975 article from Yunnan began by crediting Chairman Mao's revolutionary line, party support, and the "direct assistance" (直接帮助) of Albanian experts for the success of their olive cultivation (Yunnan Bureau of Forestry 1975). The Albanian ambassador had personally visited the site and advised that olives be grown there. Following this, the Chinese Forestry Bureau had sent a team from Yunnan to Albania for two weeks of study. They set bold projections for the future of olive oil production in Yunnan in the coming years and came to four conclusions. First, the party line must be followed, including the policy of emphasizing the production of grain over oil. Second was the planting of seedlings, and as a fallback (while there were still few olive seeds) the use of “wild olive” trees (尖叶木樨榄, Olea europaea L. spp. cuspidata, which grew abundantly in Yunnan) as stock for grafting. Third, because the broad masses were still too unfamiliar with olive tree cultivation, more emphasis needed to be placed on extension, and especially the establishment of models. Fourth and finally was a commitment to scientific research on breeding varieties suited to Yunnan's climate and soil, management technologies, and prevention of pests. Of these four conclusions, only one suggested anything especially learned from Albania or anything different from what we would expect of any agricultural science project in "Cultural Revolution" -era China. That was the injunction to plant seedlings, since of the seven propagation methods described by Albanian experts, the favored method was the cultivation of seedlings in nurseries-but given that this was the most difficult option for a place lacking mature trees to provide seeds, even here the authors emphasized the time-honored Chinese technique (albeit also known to Albanian experts) of grafting with native trees. And just as in the Shaanxi example, an article from 1971 demonstrates that the grafting method had already been embraced in Yunnan before the arrival of Albanian experts (Yunnan Forestry Science Institute Revolutionary Committee 1971).

\section{Domesticating the science of olive cultivation}

The source materials exhibit much flowery symbolic rhetoric linking the rooting of Albanian olive trees in Chinese soil with the eternal bonds of Sino-Albanian friendship, some flattering references to the Albanian experts whose assistance reportedly helped make the endeavor a success, and in the early years a systematic interest in learning about the soil and climate of Albania. However, many articles do not mention the 
Albanian experts at all. ${ }^{9}$ And those that do mention them do not go on to offer concrete examples of agricultural knowledge credited to Albanian experts and employed in Chinese experiment stations or tree farms. Being familiar enough with the rhetoric of the era, I can imagine what such examples would look like if they existed: they would herald the genius of Albanian peasants, arising from their lives spent in agricultural labor, and would select specific innovations Albanian peasants had been able to produce under the wise guidance of Albanian communist party leaders who had held true to the teachings of Marx, Lenin, and Stalin. However, the existing materials tell a story that says very little about Albanian science or Albanian expertise - but very, very much about "Cultural Revolution"-era China and its approach to mass science. At the end of the day, Albania remained far away.

When the trees arrived from Albania, they were distributed to experimental sites across China that had been identified as likely areas for olive cultivation. Charged with keeping the trees alive, tending them to maturity, and propagating them, research teams at each site mobilized the resources and knowledge at hand. In Hanzhong, Shaanxi, where tangerines are grown, they borrowed a time-honored strategy for propagating citrus, air-layering. In Yunnan and Sichuan, they turned to a native plant of the same genus, the "wild olive," and adopted grafting, a method long known for compelling a tree from one location to fruit in another (Métailié 2007). And in each successful case, the team reported the results of their experiments and, where appropriate, recommended that the methods be extended more broadly. This was the famous "point-to-plane" (由点到面) system of trying new ideas at one experimental "point" and then extending those that worked to broader regions, which dated to revolutionary times and was employed not just in agriculture but in many other areas of policy making (Heilmann 2008; Schmalzer 2016).

We also see in these documents intriguing references to Michurinist speculations about the fate of plants moved so far from their original environment, but without much in the way of concrete plans to apply such ideas to methods of acclimatization or propagation. It would be helpful to know the state of Michurinism among Albanian agricultural scientists in the 1960s and 1970s. However, in any case, the influence of Michurinism in the Chinese sources examined here appears mostly to be a very close concern with environmental conditions, which on balance was probably a benefit to the

9 In addition to the examples already discussed, see Sanmenjiang Forest Farm in Liuzhou, Guangxi 1975, which provides detailed discussions of grafting (especially with wild olive) and twig cuttage (number three on the Albanian list of propagation methods). It also offers as alternative possibilities another form of cuttage (硬枝, which seems more like Albanian method number two) and air-layering. See also "Jiji de tuiguang fazhan" 1974; Xichang Subtropical Crops Research Institute 1974; and Sichuan Forestry Science Research Institute et al. 1977. 
project (Xichang Subtropical Crops Research Institute 1974). ${ }^{10}$

Unsurprisingly, the domestic politics of the volatile "Cultural Revolution" period often tended to compete with or even at times overwhelm the emphasis on Sino-Albanian friendship. For example, a report on a conference that gathered 110 olive researchers and workers from fourteen provinces and municipalities said nothing of Albanian experts, but devoted considerable space to the Campaign to Criticize Lin Biao and Confucius ("Jiji de tuiguang fazhan" 1974). ${ }^{11}$ Other articles emphasized the grueling labor willingly expended by Chinese workers to keep the saplings alive:

In summer 1966, Wuhan was hot and dry. For 90 days there was not one day of saturating rain. The trees suffered greatly. The Forestry Science Institute staff all worked hard to combat the drought. The ponds were all dry, so they had to go several miles to the reservoir to haul water. For each shoulder-load of water hauled to moisten the earth, a tree could keep growing healthy and strong. ("Youyi zhi shu" 1972)12

More constructively, perhaps, a 1975 article from Hubei emphasized the importance of making olive cultivation a mass movement with "three-in-one groups" (三结合试验小 组, comprising cadres, peasants, and technicians) and celebrated the many innovations that had reportedly come from the masses: moving cuttages from heated greenhouses to the open air and from sand to soil, and developing a method of summer cuttage that produced an impressive $82 \%$ survival rate. We would be wise to be skeptical of most if not all such reports; my point here is to emphasize the degree to which the Sino-Albanian olive project became a part of the very familiar form of agricultural science during the "Cultural Revolution" in China, and the kind of innovations and expertise that could have been attributed to Albanian peasants if that had been a priority of the Chinese people in charge of the olive project (Wuhan Research Institute of Gardening 1975). Further in keeping with the era, the article emphasized the need for learning from others' experience-but again it is highly telling that this is interpreted solely within the standard framework of learning from other production teams in China (in this case, sending people to Guangxi, Zhejiang, and other sites within Hubei), not about learning from Albania.

Finally, after some initial interest in learning about the climate and soil of far-off Albania, the focus of reporting on the Sino-Albanian friendship trees turned toward

10 This source, for example, talks of the need to acclimate (风土驯化) the trees but then select the superior varieties and pass down the traits from generation to generation.

11 Enver Hoxha offered some pointed commentary on the campaign in his memoirs. See Halliday 1986, 299.

12 “一九六六年夏季, 武汉地区高温干旱, 连续九十天没有下过一次透雨, 油橄榄受到了严重的威 胁。林业科学研究所的职工们日夜与干旱斗争, 塘水挑光了, 就到几里路远的水库挑水抗旱。一担 担水滋润着土地, 一棵棵油橄榄树依然茁壮成长。” 
vivid and romantic descriptions of the Chinese locales in which they were planted. From Hubei we hear that "on the southern banks of the Yangtze River, below the suburb of Wuhan, Jiufengshan, there are groves of olive trees with luxuriant leaves, and many of the trees are bursting with purplish-red fruits that look like grapes" ("Youyi zhi shu" 1972). ${ }^{13}$ And in a 1975 issue of a Shaanxi forestry science journal, the growing of olives in Hanzhong, Shaanxi, alongside the region's famous "Chenggu tangerines" was worthy of a full-page photo spread ("Zhong-A youyi shu youganlan" 1975).

The Albanian olive trees continue to hold a special significance in some pockets of China today. The Haikou Tree Farm in Kunming showcases the olive trees as, in the words of one blogger, its "most unique symbol" (最独特的表征) (Yuanshan Moyu 2019). But the symbol is no longer one of Sino-Albanian friendship; the focus is instead on the leadership qualities of Premier Zhou Enlai. The tree that Zhou planted in 1964 has been named the "Premier Tree" (总理树), and a statue of Zhou has been erected beside it (Figures 1 and 2). Websites and articles on the history of olives in China similarly celebrate Zhou but barely mention the Albanian experts who accompanied him, even when they are present in the accompanying photographs (Figure 3). As Li Juzhen 李聚桢， an agricultural technician who visited Albania in 1964, wrote in a recent article on the Chinese Forestry Industry website, "The Chinese olive tree project is drenched in the loving care of Premier Zhou Enlai. We should ensure the realization of the premier's wish that the global olive oil distribution map should include the name "China'" (Chinese Forestry Industry Association 2014). ${ }^{14}$ The meaning of the Albanian olive trees has thus if anything become still more focused on the Chinese political landscape, where memories of Premier Zhou's fabled concern for the welfare of the Chinese people, along with a prominent role for China in the global economy, loom large.

\section{Conclusion}

This paper has made several intertwined arguments. First, I have shown that in newspapers, magazines, and scientific journals, the olive trees brought to China from Albania in 1964 were celebrated as symbols of Sino-Albanian friendship and of international socialist solidarity more generally. These materials frequently highlighted Albania's steadfast and courageous commitment to socialism, and some also made laudatory comments about the Albanian experts who came to China to share their knowledge about olive tree cultivation. However, I further argue that interest in

13 “在扬子江南岸、武汉市东郊的九峰山下, 有一片片枝叶繁茂的油橄榄林, 许多油橄榄树上结满 葡萄似的一颗颗紫红的果实。”

14 “中国的油橄榄事业浸透着太多周总理的关心和爱护, 我们一定要让总理想在世界橄榄油分布图 上加上 “中国” 这个名字的愿望得以实现。” 


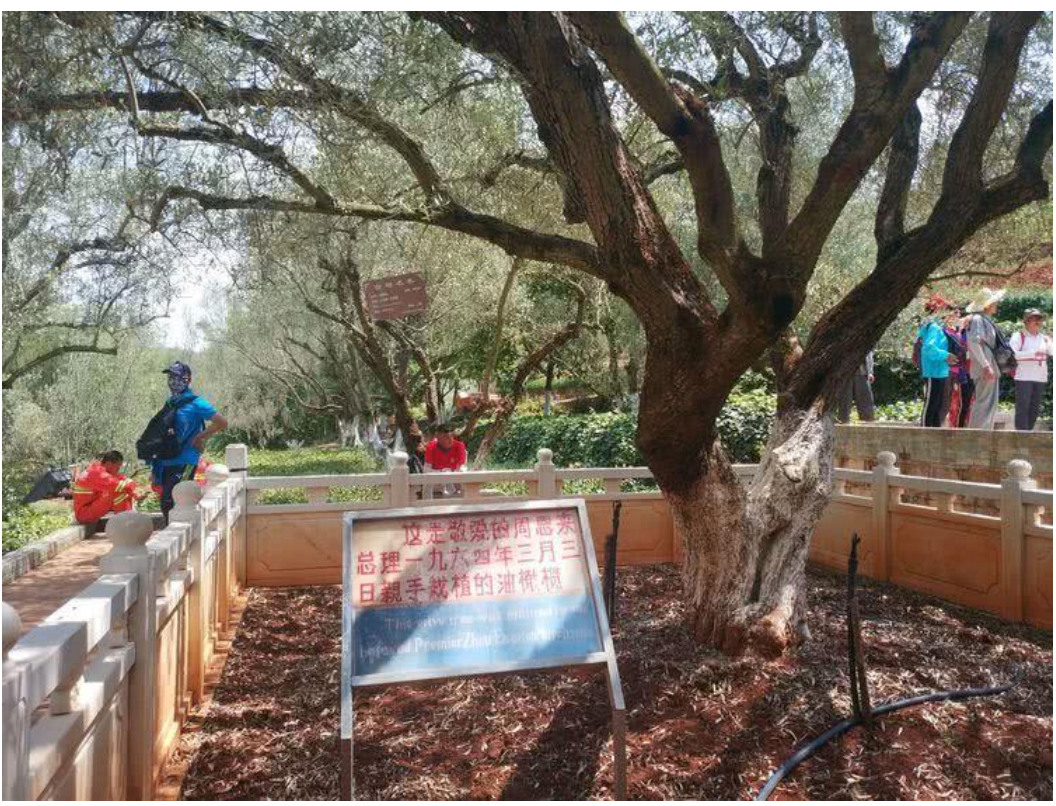

Figure 1: This photograph of the "Premier Tree" (总理树) at the Haikou Tree Farm appeared on a QQ blog in 2019. The sign reads, "This is an olive tree planted by beloved Premier Zhou Enlai with his own hands on March 3, 1964" (Yuanshan Moyu 2019).

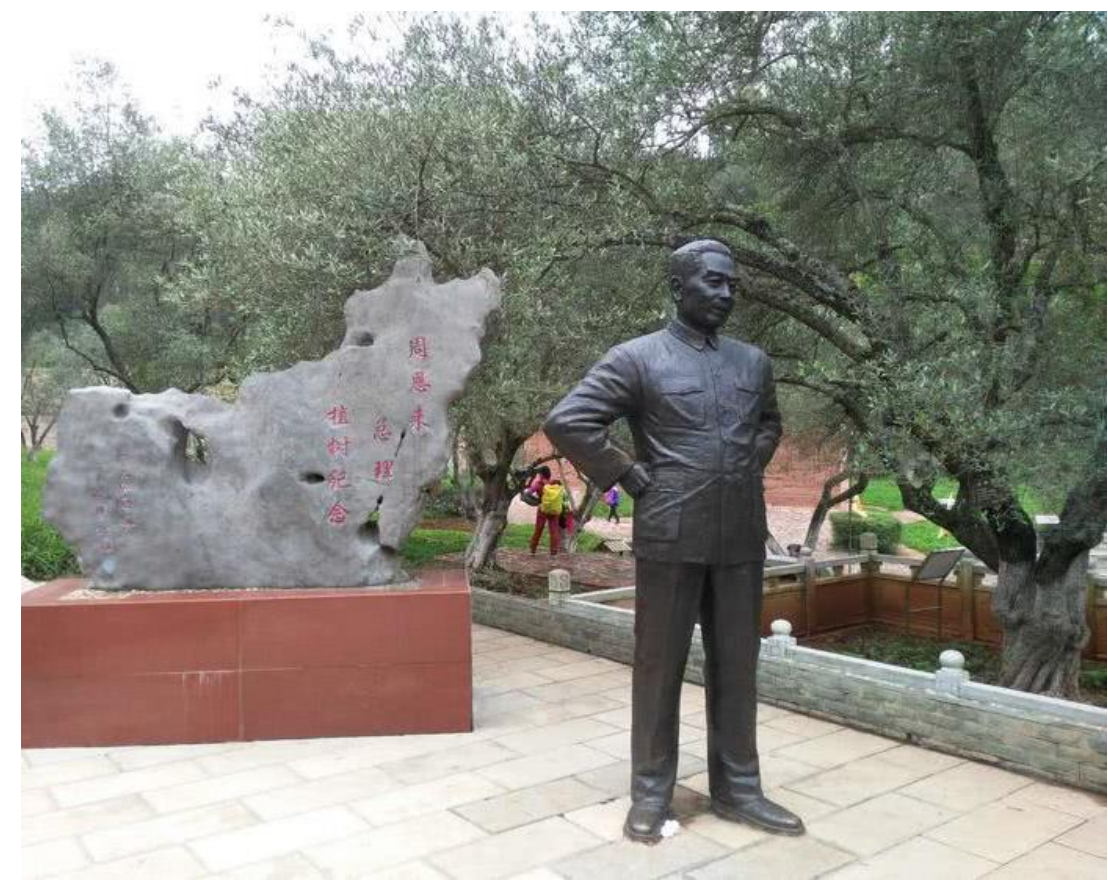

Figure 2: A photograph of a statue of Zhou Enlai and memorial stone erected next to the "Premier Tree" pictured in Figure 1 (Yuanshan Moyu 2019). 


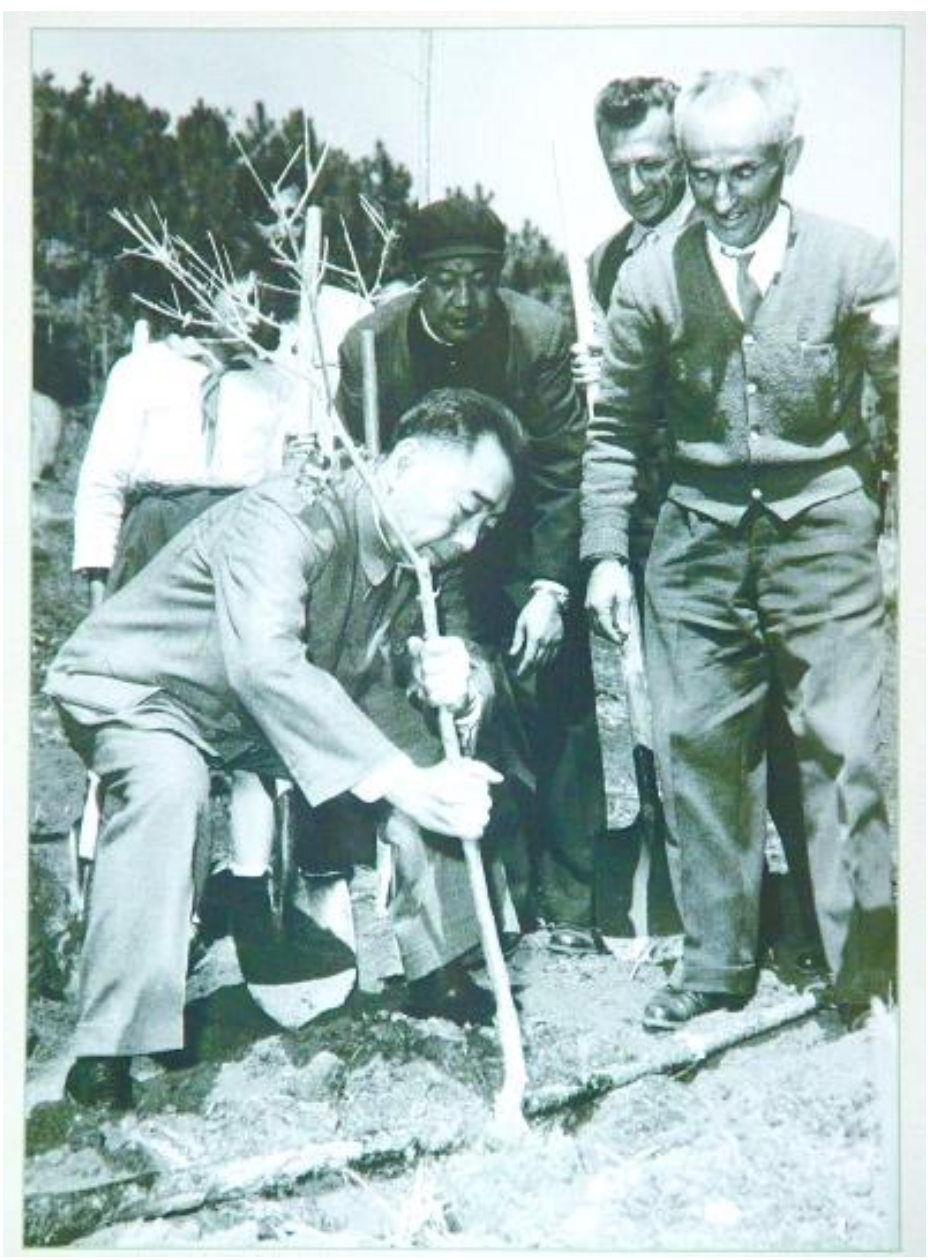

Figure 3: A photograph of Zhou Enlai planting the tree pictured in Figure 1, as it appears on the website http://www.olivewudu.com/ganlanwenhua/74.html.

Albania came to be overshadowed by interest in China's own geographic and political landscapes. Moreover, I find that the sources say very little of substance about what the Albanian experts actually contributed; still more telling, some of the evidence suggests that Chinese scientists and technicians proceeded with the acculturation process using technologies already very familiar in China, and without much apparent consideration of Albanian agricultural expertise.

Why do these sources provide so little evidence of meaningful knowledge exchange between Albania and China on this abundantly discussed subject of olive tree cultivation? Perhaps there was in fact significant exchange that the sources simply did not capture; perhaps agricultural journals were just not deemed the appropriate venues for detailed discussions of international scientific exchange. And perhaps the era's lack of rigorous citation practices prevents the reader from seeing just how much of the 
knowledge communicated arose from the specific guidance of Albanian experts. The tremendous emphasis placed on revolutionary spirit over technological matters in the reporting on many "Cultural Revolution"-era projects may also have led to a lack of documentation. However, I conclude the most important reason is probably that national-level politics (including those related to mass science and self-reliance) took priority, overwhelming the significance of international collaboration.

There is one more possibility that I think bears consideration: Chinese scientific and political cadres may well have doubted that Albanians could teach them much about agriculture. The effusively flattering rhetoric describing Albanian friends focused on their courage, heroism, and fighting spirit rather than on anything related to scientific knowledge or even the kind of earthy expertise celebrated among China's peasant masses. For all its efforts to upend traditional elitist hierarchies of knowledge, the Chinese state accepted the developmentalism that rendered some nationalities "backwards" and others "advanced." In the days of Soviet learning, China adopted a mostly humble position in relation to its "older brother." When it came to collaborating with Albania, it is easy to imagine China proudly assuming the position of elder in the ranking. It would be interesting to see how the Albanian sources painted the relationship, both in the case of the Albanian olive trees in China and the Chinese carp in Albania - but for that side of the story, we await historians of Albania who can turn their attention to the specific, but by no means esoteric, subjects of agricultural science and transnational knowledge circulation.

\section{Acknowledgments}

I thank the two anonymous reviewers along with those who organized and participated in a workshop at Columbia University in 2016 and another workshop at the Institute for the History of Natural Sciences, Chinese Academy of Sciences, in 2019, where I presented this paper and received excellent feedback. I also thank Xia Bing 夏 冰 and Yu Yueyuan 俞月圆 for their translation assistance.

\section{References}

“A'erbaniya youganlan zai Hanzhong diqu yi shouguo zhayou” 阿尔巴尼亚油橄欖在汉中地区已 收果榨油 [Hanzhong District Has Already Harvested Olives and Pressed Oil from Albanian Olive Trees]. 1971. Shaanxi nongye keji 陕西农业科技 [Shaanxi Journal of Agricultural Sciences] (5): 21.

"A'erbaniya zengsong woguo wan zhu youganlan miaomu: Zhanjiang juxing yishi jieshou A'erbaniya renmin zhengui liwu” 阿尔巴尼亚赠送我国万株油橄榄苗木: 湛江举行仪式接受阿尔 巴尼亚人民珍贵礼物 [Albania gives China 10,000 olive tree seedlings: Zhanjiang holds a ceremony to receive this precious gift from the Albanian people]. 1964. Renmin ribao 人民日报 
[People's Daily], February 19, 1964.

Afro-Asian Networks Research Collective. 2018. "Manifesto: Networks of Decolonization in Asia and Africa." Radical History Review 131: 176-182.

Baidu Baike. 2016. “Xu Weiying” 徐纬英. Accessed March 11, 2016. http://baike.baidu.com/view/ 305684.htm.

Bräutigam, Deborah. 1998. Chinese Aid and African Development: Exporting Green Revolution. New York: St. Martin's Press.

Bureau of Forestry, Ministry of Agriculture and Forestry (China) 农林部林业局, ed. 1975. Youganlan zaipei 油橄榄栽培 [Cultivation of olives]. Beijing: China Agriculture Press.

Chinese Forestry Industry Association. 2014. "Youganlan, cong 'sannian kunnan' dao 'shiyou anquan” 油橄榄, 从 “三年困难” 到 “食油安全” [Olive trees, from “Three Years of Hardship” to “Oil Safety"]. Accessed November 10, 2019. http:/ / www.chinalycy.com/Item/2382.aspx.

“Daonian zhuming linmu yuzhong xuejia Xu Weiying xiansheng” 悼念著名林木育种学家徐纬英 先生 [Mourning the famous tree breeding specialist Xu Weiying]. 2009. Linye kexue yanjiu 林业 科学研究 [Forest Research] 22 (2): 152.

Deng, Yu 邓煜. 2014. “Jinian Zhou Enlai zongli yinzhong youganlan” 纪念周恩来总理引种油橄 榄 [Commemorating 50 years since Premier Zhou Enlai introduced olives]. Accessed November 10, 2019. http://olive.org.cn/ShowNews8.asp?id=82.

Fan, Fa-ti. 2012. "The Global Turn in the History of Science." East Asian Science, Technology $\mathcal{E}$ Society 6 (2): 249-258.

Halliday, Jon, ed. 1986. The Artful Albanian: Memoirs of Enver Hoxha. London: Chatto \& Windus.

Heilmann, Sebastian. 2008. "From Local Experiments to National Policy: The Origins of China's Distinctive Policy Process." China Journal 59: 1-30.

Hopwood, Nick. 1996. "Producing a Socialist Popular Science in the Weimar Republic." History Workshop Journal 41: 117-153.

"Jiji de tuiguang fazhan Zhong A youyi shu - youganlan: Shisi sheng, shi, qu youganlan jingyan jiaoliu xianchanghui zai Liuzhou zhaokai” 积极地推广发展中阿友谊树一一油橄榄: 十四省、市、 区油橄榄经验交流现场会在柳州召开 [Actively extend and develop the Sino-Albanian friendship trees, olives: Meeting held in Liuzhou to exchange experiences on olives by fourteen provinces, municipalities, and districts]. 1974. Linye keji tongxun 林业科技通讯 [Forestry Science and Technology] (1): 10.

Le, Tianyu 乐天宇, and Xu Weiying 徐纬英. 1957. Shaanganning Pendi zhiwu zhi 陝甘宁盆地植物 志 [Botanical gazetteer of the Shaanxi-Gansu-Ningxia Basin Flora]. Beijing: China Forestry Press.

Lushan Agricultural Bureau, and Lushan Botanical Garden. 1973. "Youganlan qiancha fanzhi" 油橄榄扦插繁殖 [Olive tree cuttage and propagation]. Linye keji 林业科技 [Forestry Science \& Technology] (3): 11-12.

Mëhilli, Elidor. 2017. From Stalin to Mao: Albania and the Socialist World. Ithaca: Cornell University Press.

Métailié, Georges. 2007. “Grafting as an Agricultural and Cultural Practice in Ancient China." In Botanical Progress, Horticultural Innovations and Cultural Changes, edited by Michael Conan and W. John Cress, 147-158. Washington, DC: Dumberton Oaks Research Library and Collection.

Monson, Jamie. 2009. Africa's Freedom Railway: How a Chinese Development Project Changed Lives 
and Livelihoods in Tanzania. Bloomington: Indiana University Press.

Nanwutai Experiment Station of Shaanxi Forestry Research Institute. 1973. "Youganlan duozhi gaokong yatiao yumiao" 油橄榄多枝高空压条育苗 [Multi-branch air layering in olive trees]. Shaanxi linye keji 陕西林业科技 [Shaanxi Forest Science and Technology] (2): 16-17.

Reardon-Anderson, Charles. 1991. The Study of Change: Chemistry in China, 1840-1949. Cambridge: Cambridge University Press.

Research Institute of Forestry Science in Ganzhou, Jiangxi. 1973. "Youganlan yinzhong shiyan chubao" 油橄榄引种试验初报 [Preliminary report on experiments introducing olives]. Linye keji (2): 8-11.

Sanmenjiang Forest Farm in Liuzhou, Guangxi. 1975. “Youganlan de fanzhi jishu” 油橄榄的繁殖 技术 [Olive propagation technology]. Zhiwuxue zazhi 植物学杂志 [Botany magazine] (1): 9-11.

Schmalzer, Sigrid. 2008. The People's Peking Man: Popular Science and Human Identity in Twentieth-Century China. Chicago: University of Chicago Press.

Schmalzer, Sigrid. 2014. "Self-Reliant Science: The Impact of the Cold War on Science in Socialist China." In Science and Technology in the Global Cold War, edited by Naomi Oreskes and John Krige, 75-106. Cambridge: MIT Press.

Schmalzer, Sigrid. 2016. Red Revolution, Green Revolution: Scientific Farming in Socialist China. Chicago: University of Chicago Press.

Shapin, Steven, and Barry Barnes. 1976. "Head and Hand: Rhetorical Resources in British Pedagogical Writing, 1770-1850." Oxford Review of Education 2 (3): 231-254.

Shen, Grace Yen. 2013. "Going with the Flow: Chinese Geology, International Scientific Meetings and Knowledge Circulation." In The Circulation of Knowledge between Britain, China and India: The Early Modern World to the Twentieth Century, edited by Bernard Lightman et al, 237-260. Leiden: Brill.

Sichuan Forestry Science Research Institute 四川省林业科学研究所 et al. 1977. “Youganlan qingkubing de fangzhi shiyan" 油橄榄青枯病的防治试验 [Experiments treating wilt disease in olives]. Zhongguo linye kexue 中国林业科学 [Scientia Silvae Sinicae] (3): 61-66.

Songster, Elena. 2018. Panda Nation: Nature, Science, and Nationalism in the People's Republic of China: The Construction and Conservation of China's Modern Icon. Oxford: Oxford University Press.

Wang, Jian 王剑. 2013. “Zhang Li: Huan nü kexuejia yige zhenshi xingxiang” 张藜: 还女科学家 一个真实形象 [Zhang Li: Give women scientists back their true image]. Zhongguo kexue bao 中 国科学报 [China Science Daily], March 4, 2013.

“Woguo li lian yumiao zai A'erbaniya chengzhang zhengchang” 我國鯉鰱魚苗在阿尔巴尼亞成長 正常 [Chinese fingerling carp maturing normally in Albania]. 1959. Zhongguo shuichan 中国水 产 [Chinese Fisheries] (18): 22.

Wuhan Research Institute of Gardening. 1975. "Yinzhong fanzhi youganlan de qingkuang huibao" 引种繁殖油橄榄的情况汇报 [Report on the introduction and cultivation of olive trees]. Hubei linye keji 湖北林业科技 [Hubei Forestry Science and Technology] (2): 15-19.

Xichang Subtropical Crops Research Institute. 1974. "Rang youyi shu genghao de chuanzong jiedai-A'erbaniya youganlan yu jianye muxilan jiajiemiao zai wo qu kaihua jieshi” 让友谊树 更好地传宗接代一一阿尔巴尼亚油橄榄与尖叶木槉榄嫁接苗在我区开花结实 [Allow the friendship trees to better carry on their ancestral line: Albanian olive trees grafted on Osmanthus have flowered and born fruit in our district]. Sichuan linye keji tongxun 四川林业科 
技通讯 [Journal of Sichuan Forestry Science and Technology] (3): 4 .

“Xiangzheng Zhongguo A'erbaniya liangguo renmin geming youyi wangu changqing: 'Zhong A youyi shu' zai woguo zhuozhuang chengzhang kaihua jieguo" 象征中国阿尔巴尼亚两国人民 革命友谊万古长青: “中阿友谊树” 在我国茁壮成长开花结果 [Symbolizing the eternal revolutionary friendship of the Chinese and Albanian People: The "Sino-Albanian Friendship Trees" thrive, mature, flower, and bear fruit in China]. 1970. Renmin ribao, December 6, 1970.

Xu, Weiying. 1981. “Youganlan zai woguo de yinzhong” 油橄榄在我国的引种 [The introduction of olive trees to China]. Linye kexue (1): 78-83.

Xu, Weiying, ed. 2004. Youganlan jiqi zaipei jishu 油橄榄及其栽培技术 [Olives and their cultivation technologies]. Beijing: China Forestry Press.

Xu, Weiying, and Han Yifan 韓一凡. 1965. “A'erbaniya youganlan jiqi zai woguo yinzhong de yanjiu” 阿尔巴尼亚油橄欖及其在我国引种的研究 [Research on Albanian olive trees and their introduction in China]. Linye kexue 林业科学 [Scientia Silvae] 10 (1): 86-99.

Yang, Dongsheng 杨冬生. 2005. “Yindi zhiyi, yong kexue fazhan guan tuidong youganlan chanye yuanxing” 因地制宜, 用科学发展观推动油橄榄产业远行 [Suiting local conditions, using the Scientific Development Outlook to promote the olive industry far from home]. Zhongguo linye chanye 中国林业产业 [China Forestry Industry] (10): 43-45, 48.

Youganlan: A'erbaniya zhuanjia Ji Muqiao, Dai Ka'erdani, Sang Chamo jiangke cailiao 油橄榄: 阿尔巴 尼亚专家季 ·姆乔、代・卡尔达尼、桑 - 查莫讲课材料 [Olive trees: Lecture materials from Albanian experts Ji Muqiao, Dai Ka'erdani, and Sang Chamo]. 1973. Beijing: China Agriculture Press.

“Youyi zhi shu zai Yangzijiang pan kaihua jieguo" 友谊之树在扬子江畔开花结果 [Friendship Trees flower and bear fruit on the bank of the Yangtze River]. 1972. Renmin ribao, November 9, 1972.

Yuanshan Moyu 远山墨雨. 2019. “Guonei di yi zhu youganlan shu zhong zai zheli” 国内第一株 油橄榄树种在这里 [The first olive tree in the country was planted here]. Tencent Web 腾讯网. https://new.qq.com/omn/20190514/20190514A0P14Q.html.

Yunnan Bureau of Forestry. 1975. “Jiaqiang Zhong A youyi, jiji fazhan youganlan: Yunnan Sheng yinzhong A'erba'niya youganlan jiankuang” 加强中阿友谊, 积极发展油橄榄一一云南省引种阿 尔巴尼亚油橄榄简况 [Strengthen Sino-Albanian friendship, actively develop olives: Report on the introduction of Albanian olive trees in Yunnan]. Yunnan linye keji tongxun 云南林业科技通 讯 [Journal of West China Forestry Science] (3): 8-9.

Yunnan Forestry Science Institute Revolutionary Committee. 1971. "Zhong A youyi wangu changqing: Zhong A youyi shu - youganlan zai wosheng kaihua jieguo" 中阿友谊万古长青 中 阿友谊树——油橄榄在我省开花结果 [The Sino-Albanian friendship will live forever: The Sino-Albanian friendship trees, olives are flowering and bearing fruit in our province]. Linye jishu tongxun 林业技术通讯 [Forest Science and Technology] (6): 9.

“Zhong-A youyi shu youganlan zai wosheng Hanzhong Pendi shengkai youyi hua” 中阿友谊树 油橄榄在我省汉中盆地盛开友谊花 [Sino-Albanian friendship olive trees in the Hanzhong Basin of Shaanxi Province are bursting with friendship flowers]. 1975. Shaanxi linye keji (1): 2.

Zou, Dongxin. 2019. "Socialist Medicine and Maoist Humanitarianism: Chinese Medical Missions to Algeria, 1963-1984." PhD diss., Columbia University. 